\title{
Effect of Xylitol Chewing Gum on Dental Plaque, Sali- va Flow and Saliva Buffer Capacity in Chilean Youngsters
}

\author{
Efecto de Chicles con Xilitol sobre Placa Bacteriana, Flujo Salival \\ y Capacidad Buffer de la Saliva en Adolescentes Chilenos \\ Manuel Felipe Velásquez Castilla* \& Carmen Gloria Narváez Carrasco*
}

\begin{abstract}
VELÁSQUEZ, C. M. F. \& NARVÁEZ, C. C. G. Effect of xylitol chewing gum on dental plaque, saliva flow and saliva buffer capacity in Chilean youngsters. Int. J. Odontostomat., 7(1):133-137, 2013.

ABSTRACT: Prevention is the area of dentistry that should be given more emphasis to reduce further consequences on the oral cavity. The aim of this study was to assess the use of xylitol chewing gum on dental plaque, saliva flow and saliva buffer capacity in youngster. Fifteen dental students were randomly assigned to a study and control group, the first received a xylitol chewing gum while the second a placebo chewing gum, provided 4 times per day for 21 days. Dental plaque, saliva flow and saliva ph were measures at day $0,7,14$ and 21 st. Dental plaque concentration decreased in both groups $(p>0,05)$, saliva flow increased $(p>0,05)$ and saliva ph was incremented but no significant differences were found among groups $(p>0,05)$. The use of xylitol chewing gum helps to reduce dental plaque, increase saliva flow and ph, like the placebo chewing gum, but a larger study is needed to properly assess if xylitol has an additional benefit on the studied variables.
\end{abstract}

KEY WORDS: xylitol, chewing gum, dental plaque, saliva, hydrogen-ion concentration.

\section{INTRODUCTION}

Over the last years, preventive dentistry has become an important issue among professionals, especially by the development of new methods to prevent plaque. Among them, the use of chewing gum containing sugar alcohols is being practiced more often (Ribelles Llop et al., 2010). All sugar alcohols, like xylitol, sorbitol and mannitol, have been tested for fermentation by oral bacteria and can be classified as hypo- or non-acidogenic, therefore low or noncariogenic (van Loveren, 2004). Among these sugar alcohols, xylitol is believed to possess anticaries properties (van Loveren), reducing caries incidence from 30 to $65 \%$ (Wennerholm et al., 1994). Anderson (2003) stated that xylitol produces an unfavorable environment for the Streptococcus mutans, reducing the adherence to oral tissues therefore affecting its capacity to form dental plaque. Other authors concluded that xylitol penetrates into the bacterial cytoplasm, interferes with glycolysis and results in cell growth inhibition (van Loveren; Fraga et al., 2004). This anti caries property may also be related to the fact that chewing gum produces a stimulation and increment in saliva production, therefore increasing the buffer capacity of it as well (Ribelles Llop; Fraga et al.).
The use of chewing gum and lozenges for oral care purposes is a practical method and easy to disseminate in the community (Borhan-Mojabi et al., 2012). Holgerson et al. (2007), showed a significant reduction of dental plaque among children from 6 to 12 years old when using xylitol chewing gum. With all this information gathered, children would benefit significantly in reducing dental plaque formation if xylitol chewing gum is used, but there is few information about its use in young patients. The objective of the study was to assess the use of xylitol chewing gum on dental plaque, saliva flow and saliva buffer capacity in Chilean youngsters.

\section{MATERIAL AND METHOD}

Fifteen subjects, out of 61 , voluntarily participated in this simple blind, randomized pilot study. Subjects eligible for study inclusion had to be studying fifth year of dentistry at the Universidad Del Desarrollo and consented to study acceptance. Subjects were excluded for study enrollment if they were under orthodontic treatment; affected by a disease that could reduce the 
saliva quality or quantity; affected by a TMJ disease that could limit the ability to chew; present caries and/ or periodontal disease.

A random assignment was performed to build the study and control group. The study group received an Orbit $\circledast$ White xylitol chewing gum freshmint flavored (Wrigley Jr. Company, Peoria, USA), while the control group received a sorbitol Bigtime Dent $₫$ chewing gum spearmint flavored (Industria de Alimentos Dos en Uno S.A., Santiago, Chile). At time 0 the participants provided a saliva sample stimulated by a Parafilm $\AA$ sheet $(5 \times 5$ $\mathrm{cm}$ ) (Pechiney Plastic Packaging Company, Chicago, USA). Saliva samples were collected for one minute in sterile sample tubes of $15 \times 100 \mathrm{~mm}$ with a cotton cover and were placed in a refrigerator at $4^{\circ} \mathrm{C}$. Dental plaque was measured using the O'Leary index, which indicates the proportion of stained dental surfaces. Each tooth is assumed to have four surfaces (distal, mesial, lingual/ palatal and buccal) and the total of stained surfaces is divided by the total available surfaces and then multiplied by 100 . At the end of the sampling procedure a basic prophylaxis was performed using brushes and NUPRO ${ }^{\circledR}$ paste (Dentsply, York, USA). After that, chewing gums were provided according a protocol described by Manton et al. (2008) where they were instructed to chew the chewing gum during $20 \mathrm{~min}, 4$ times per day, for 21 days. The chewing gums were provided in an unlabeled plastic bag.

All subjects attended a control at days 7,14 , and 21. They were asked not to change the usual diet or the hygiene habits during such period. At the microbiology laboratory the ph was measured using a Hanna ${ }^{\circledR} \mathrm{HI}$ $221 \mathrm{pH}$-meter (Hanna Instruments, Woonsocket, USA) directly from the sample tube. Using a disposable test tube, $1 \mathrm{ml}$ of saliva was placed in a different tube to be mixed with $0.005 \%$ hydrochloric acid and let it rest for 20 minutes to measure ph after that. All the procedures followed the ethical norms set by the 2000 Helsinki declaration and sanitary protocols. To determine significant differences through the time in the O'Leary index, saliva flow and saliva buffer capacity, a repetitive measures analysis was performed.

\section{RESULTS}

Six female and nine male participated in this randomized pilot study. All the subjects attended the control sessions and comply with the study protocols. Table I shows the general data. Figure 1 shows plaque index variation before and after treatment, not showing

Table I. O'Leary index, saliva flow and saliva buffer $\mathrm{pH}$ initial and final. Treatment (Tx) 1 corresponds to xylitol chewing gum, and treatment 0 to sorbitol chewing gum. The subjects (Ss) average age was 23 years.

\begin{tabular}{|c|c|c|c|c|c|c|c|c|c|c|c|c|c|c|c|c|c|c|c|}
\hline \multirow{3}{*}{ Ss } & \multirow{3}{*}{$T x$} & \multirow{3}{*}{ Sex } & \multirow{3}{*}{ Age } & \multirow{2}{*}{\multicolumn{4}{|c|}{$\begin{array}{c}\text { O'Leary Index (\%) } \\
\text { Day }\end{array}$}} & \multicolumn{4}{|c|}{$\begin{array}{l}\text { Saliva Flow } \\
\text { (ml/min) }\end{array}$} & \multicolumn{4}{|c|}{$\begin{array}{c}\text { Saliva Buffer } \\
\text { Capacity - Initial pH }\end{array}$} & \multicolumn{4}{|c|}{$\begin{array}{c}\text { Saliva Buffer } \\
\text { Capacity - Final pH }\end{array}$} \\
\hline & & & & & & & & & & & & & & Day & & & & ay & \\
\hline & & & & 0 & 7 & 14 & 21 & 0 & 7 & 14 & 21 & 0 & 7 & 14 & 21 & 0 & 7 & 14 & 21 \\
\hline 1 & 1 & $M$ & 22 & 42 & 18 & 15 & 13 & 6 & 6 & 5.2 & 8 & 7.39 & 7.11 & 7.2 & 7.63 & 5.22 & 5.18 & 4.9 & 6.05 \\
\hline 2 & 0 & $M$ & 23 & 20 & 13 & 18 & 13 & 2.8 & 2 & 2.5 & 2.5 & 7.35 & 7.47 & 7.4 & 7.43 & 3.91 & 2.35 & 3.98 & 3.62 \\
\hline 3 & 1 & $M$ & 23 & 22 & 13 & 5 & 5 & 3 & 3.5 & 3.5 & 4 & 7.51 & 7.58 & 7.5 & 7.41 & 5.85 & 5.7 & 5.99 & 5.68 \\
\hline 4 & 0 & $M$ & 24 & 52 & 21 & 17 & 11 & 3.8 & 2 & 3 & 3.5 & 7.18 & 6.91 & 7.13 & 7.26 & 3.61 & 2.7 & 4.33 & 5.16 \\
\hline 5 & 1 & $M$ & 23 & 69 & 15 & 14 & 13 & 3.2 & 3 & 3 & 3 & 6.85 & 6.83 & 7.11 & 7.37 & 5.11 & 4 & 4.41 & 4.55 \\
\hline 6 & 0 & $F$ & 23 & 63 & 22 & 15 & 15 & 3 & 3 & 4 & 3.5 & 7.03 & 6.85 & 7.05 & 7.41 & 4.33 & 4 & 4.06 & 4.4 \\
\hline 7 & 1 & $\mathrm{~F}$ & 22 & 28 & 25 & 16 & 14 & 1.8 & 1.5 & 1.5 & 1.5 & 6.76 & 6.78 & 6.85 & 6.87 & 2.56 & 2.65 & 2.62 & 2.6 \\
\hline 8 & 0 & $F$ & 23 & 28 & 9 & 8 & 8 & 1.2 & 1.8 & 1.5 & 1.5 & 7.2 & 7.07 & 7.46 & 7.75 & 2.7 & 3.82 & 4.99 & 3.1 \\
\hline 9 & 1 & $M$ & 22 & 23 & 20 & 18 & 18 & 2.7 & 1.8 & 2 & 2.5 & 7.17 & 6.74 & 7 & 7.53 & 5.12 & 3 & 4.03 & 4.15 \\
\hline 10 & 0 & $M$ & 23 & 23 & 13 & 13 & 10 & 1.2 & 1.3 & 2 & 2 & 7.33 & 8.02 & 7.7 & 7.83 & 4.52 & 5.34 & 5.21 & 5.31 \\
\hline 11 & 0 & $\mathrm{~F}$ & 23 & 43 & 15 & 14 & 13 & 2.8 & 3.1 & 3 & 3.2 & 7.56 & 7.7 & 7.41 & 7.59 & 4.2 & 3.64 & 3.5 & 3.93 \\
\hline 12 & 1 & $M$ & 23 & 63 & 17 & 16 & 15 & 2.7 & 4.8 & 5 & 5 & 7.58 & 7.44 & 7.51 & 7.53 & 5.53 & 5.1 & 4.86 & 5.21 \\
\hline 13 & 0 & $F$ & 22 & 70 & 30 & 21 & 17 & 2 & 1.7 & 2.5 & 3.5 & 7.44 & 7.49 & 7.28 & 6.88 & 4.1 & 5.13 & 3.95 & 4.12 \\
\hline 14 & 1 & $F$ & 22 & 63 & 22 & 20 & 15 & 2.2 & 4 & 4.5 & 4 & 7.44 & 7.43 & 7.31 & 7.42 & 5.35 & 5.55 & 5.65 & 5.63 \\
\hline 15 & 0 & $M$ & 22 & 78 & 16 & 15 & 16 & 3 & 3.5 & 5 & 5 & 6.88 & 7.04 & 7.25 & 7.31 & 3.74 & 3.4 & 3.83 & 3.86 \\
\hline
\end{tabular}


statistically significant differences $(p>0.05)$. The O'Leary index average was reduced from $40.5 \%$ to $11.5 \%$ in the treatment group and from $57.88 \%$ to $14.88 \%$ in the control group. The saliva flow (Fig. 2) increased from and average 3.1 to 3.4 and 2.7 to 3.8

\section{O'Leary Index}

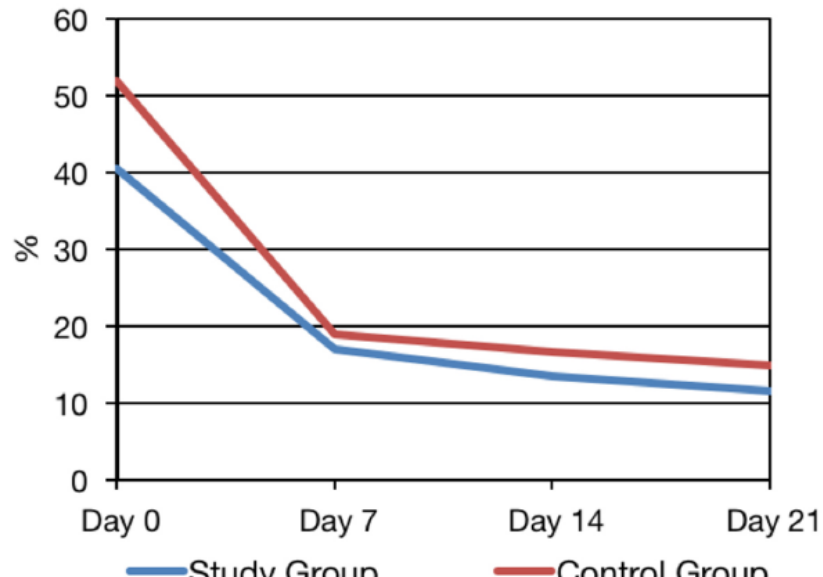

Fig. 1. O'Leary index (\%) average of study and control group at days $0,7,14$ and 21 st.

\section{Saliva Flow}

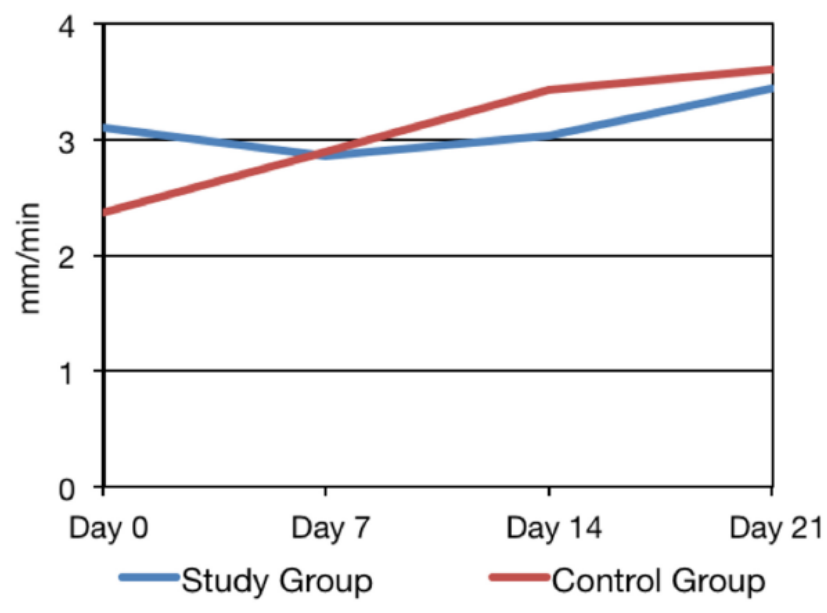

Fig. 2. Saliva flow ( $\mathrm{ml} / \mathrm{min}$ ) average of study and control group at days $0,7,14$ and 21 st.

\section{DISCUSSION}

The purpose of the study was to assess the use of xylitol chewing gum on dental plaque, saliva flow and saliva buffer capacity in Chilean youngsters. The in the study and control group respectively, but not significant differences were found after 21 days $(p>0.05)$. Saliva buffer capacity variation is shown in Figures 3 and 4, no significant differences were found $(p>0.05)$.

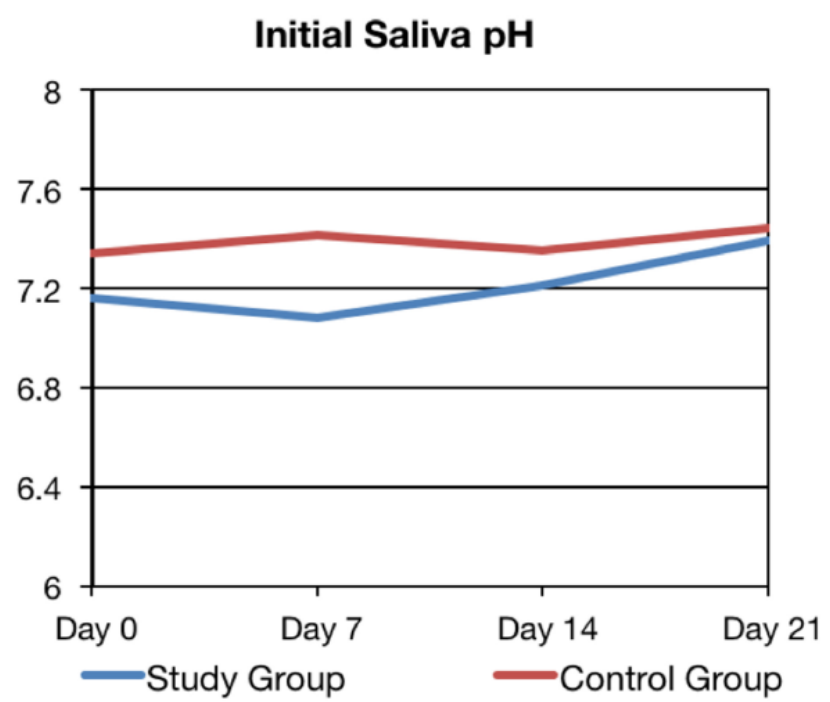

Fig. 3. Initial saliva $\mathrm{pH}$ average of study and control group at days $0,7,14$ and 21 st.

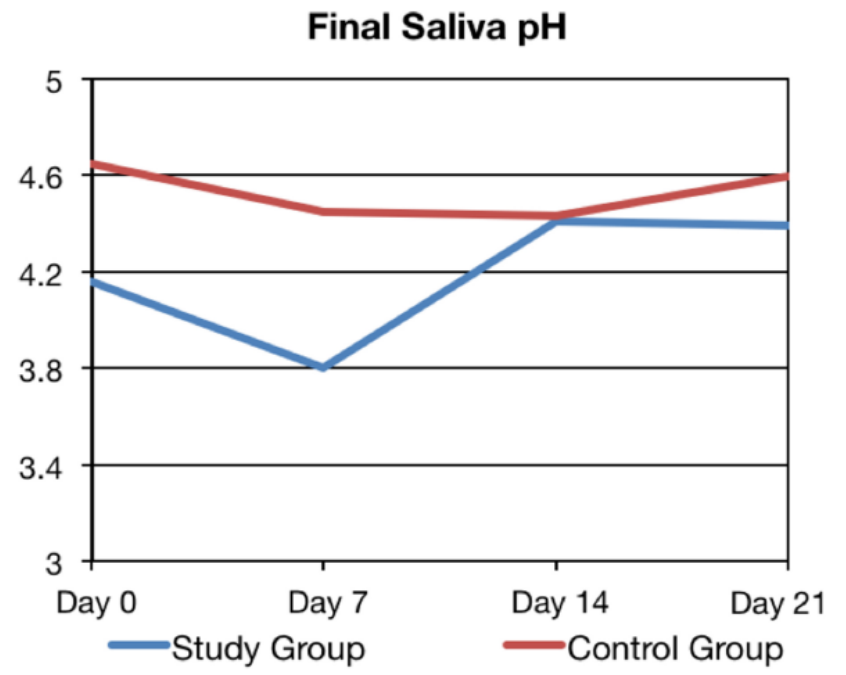

Fig. 4. Final saliva $\mathrm{pH}$ average of study and control group at days $0,7,14$ and 21 st.

study confirms what other researchers have shown related to the effect of xylitol chewing gum in reducing plaque (Anderson; Borhan-Mojabi et al.; Holgerson et 
al.; Machiulskiene et al., 2001). Dental plaque was reduced in the study and control group between day 0 and 21st. Besides the effect of the use of xylitol and the mechanical action of chewing gum on the dental plaque the researchers believe there was a personal interest of each participant to demonstrate a better O'Leary index since they were dental students. It was noticeable the interest of each participant to know the index record at each control and compare it with the previous. The researchers believe they changed the hygiene behavior even when they were told to maintain their usual habit and unconsciously they placed more attention to toothbrushing.

Like the study of Holgerson et al., there was no significant difference in the reduction of dental plaque when consuming chewing gum with xylitol or sorbitol, which indicates that both alcoholic sugars have good properties to reduce the load of plaque. Saliva flow increased in both groups but it was greater in the control group. This could be an indication that sorbitol is more effective in producing saliva flow than xylitol. This differs from the study of Manton et al., where they showed greater saliva flow production with xylitol than with sorbitol/mannitol. Future studies should include an additional group consuming a chewing gum without alcoholic sugar to test if the increment of saliva flow is due to the sugar alcohols of only due to the act of chewing (Machiulskiene et al.). The saliva ph increased in both groups and no significant differences were found among them. This may indicate that buffer capacity is favored by chewing process itself (Machiulskiene et al.).

It can be concluded that the use of xylitol chewing gum associated to oral hygiene could be a good prevention scheme to control dental plaque and reduce the risk of caries, in youngsters and children (Borhan-Mojabi et al.). However, xylitol can be administered by other vehicles like sweets, which have a good acceptance by children and have a similar effect than chewing gum (Antonio et al., 2011). This study could also be used as an initial work to test a greater sample of individuals, using sugar free chewing gums and exploring the existence of significant differences among the groups studied. Finally, according to the results, it is concluded that the use of xylitol chewing gum reduces dental plaque, increases saliva flow and reinforces saliva buffer capacity; but no significant differences were found when compared to the control group.

VELÁSQUEZ, C. M. F. \& NARVÁEZ, C. C. G. Efecto de chicles con xilitol sobre placa bacteriana, flujo salival y capacidad buffer de la saliva en adolescentes chilenos. Int. J. Odontostomat., 7(1):133-137, 2013.

RESUMEN: La prevención es el área de la odontología a la que se le debe dar más énfasis para disminuir posteriores consecuencias sobre la cavidad oral. El objetivo de este estudio fue evaluar el efecto del uso de chicles con xilitol sobre placa bacteriana, flujo salival y capacidad buffer de la saliva en jóvenes. Participaron 15 alumnos de quinto año, se asignaron al azar en un grupo de estudio y un grupo control, consumiendo chicles con xilitol y un placebo respectivamente, 4 veces al día por 21 días. Se midió placa bacteriana, flujo salival y capacidad buffer de la saliva al día 0, 7, 14 y 21. La placa bacteriana se redujo en ambos grupos tras 21 días de tratamiento sin obtener valores significativos $(p>0,05)$. Asimismo el flujo salival aumentó tanto en el grupo de estudio como en el grupo de control, pero sin encontrar resultados significativos $(p>0,05)$. El pH salival aumentó en ambos grupos, sin obtener valores significativos $(p>0,05)$. Los resultados sugieren quemasticar chicles con xilitol disminuye la placa bacteriana, aumenta el flujo salival y la capacidad buffer de la saliva, pero estudios con un mayor número de pacientes deberían realizarse para obtener valores significativos.

PALABRAS CLAVE: xilitol, chicle, placa bacteriana, saliva, pH

\section{REFERENCES}

Anderson, M. Chlorhexidine and xylitol gum in caries prevention. Spec. Care Dentist., 23(5):173-6, 2003.

Antonio, A. G.; Pierro, V. S. \& Maia, L. C. Caries preventive effects of xylitol-based candies and lozenges: a systematic review. J. Public Health Dent., 71(2):117-24, 2011.

Borhan Mojabi, K.; Mozaffari, A.; Latifi, B. \& Azin, V. Effect of chewing xylitol gum on plaque accumulation on teeth surfaces. J. Res. Dent. Sci, 8(4):1-2, 2012.

Fraga, C. P.; Mayer, M. P. \& Rodrigues, C. R. Use of chewing gum containing $15 \%$ of xylitol and reduction in mutans streptococci salivary levels. Braz. Oral Res., 24(2):1426, 2004.

Holgerson, P.; Sjöström, I.; Stecksén-Blicks, C. \& Twetman, $S$. Dental plaque formation and salivary mutans streptococci in schoolchildren after use of xylitol- 
VELÁSQUEZ, C. M. F. \& NARVÁEZ, C. C. G. Effect of xylitol chewing gum on dental plaque, saliva flow and saliva buffer capacity in Chilean youngsters. Int. J. Odontostomat., 7(1):133-137, 2013.

containing chewing gum. Int. J. Paediatr. Dent., 17(2):7985, 2007.

Machiulskiene, V.; Nyvad, B. \& Baelum, V. Caries preventive effect of sugar-substituted chewing gum. Community Dent. Oral Epidemiol., 29(4):278-88, 2001.

Manton, D. J.; Walker, G. D.; Cai, F.; Cochrane, N. J.; Shen, P. \& Reynolds, E. C. Remineralization of enamel subsurface lesions in situ by the use of three commercially available sugar-free gums. Int. J. Paediatr. Dent., 18(4) :284-90, 2008.

Ribelles Llop, M.; Guinot Jimeno, F.; Mayné Acién, R. \& Bellet Dalmau, L. Effects of xylitol chewing gum on salivary flow rate, $\mathrm{pH}$, buffering capacity and presence of Streptococcus mutans in saliva. Eur. J. Paediatr. Dent., 11(1):9-14, 2010.

van Loveren, C. Sugar Alcohols: What Is the Evidence for Caries-Preventive and Caries-Therapeutic Effects? Caries Res., 38(3):286-93, 2004.

Wennerholm, K.; Arends, J.; Birkhed, D.; Ruben, J.; Emilson, C. G. \& Dijkman, A. G. Effect of xylitol and sorbitol in chewing-gums on mutans streptococci, plaque $\mathrm{pH}$ and mineral loss of enamel. Caries Res., 28(1):48-54,1994.

\author{
Correspondence to: \\ Manuel Velásquez Castilla \\ Facultad de Odontología \\ Universidad del Desarrollo \\ Barros Arana 1735 \\ Concepción \\ CHILE
}

Fono-Fax 56-41-2268814

Email: manuelvelasquez@udd.cl.

Received: 02-10-2012

Accepted: 19-11-2012 